\title{
Growth potential of primed Moringa oleifera varieties under nursery and field conditions of Potohar region-Pakistan
}

\author{
Sami Ullah ${ }^{1,3 *}$, Shah Fahad ${ }^{1}$, Noman Latif ${ }^{1}$, Sarwat Naz Mirza ${ }^{2}$, Haroon \\ Shahzad $^{1}$, Muhammad Rizwan ${ }^{3}$ and Muhammad Arshad Khan ${ }^{1}$ \\ 1. Pakistan Agricultural Research Council, Arid Zone Research Centre, DI Khan-Pakistan \\ 2. PMAS, Arid Agriculture University, Rawalpindi-Pakistan \\ 3. Department of Agronomy, University of Agriculture, Faisalabad-Pakistan \\ *Corresponding author's email: samiullahms89@yahoo.com
}

Citation

Sami Ullah, Shah Fahad, Noman Latif, Sarwat Naz Mirza, Haroon Shahzad, Muhammad Rizwan and Muhammad Arshad Khan. Growth potential of primed Moringa oleifera varieties under nursery and field conditions of Potohar regionPakistan. Pure and Applied Biology. Vol. 8, Issue 1, pp813-319. http://dx.doi.org/10.19045/bspab.2019.80023

\begin{tabular}{llll}
\hline \hline Received: 06/08/2018 & Revised: 05/01/2019 & Accepted: 09/02/2019 & Online First: 20/02/2019 \\
\hline \hline
\end{tabular}

\section{Abstract}

Moringa oleifera is a fast emergent multiuse tree. It is protein rich and is used as human food, cattle fodder and medicine. Present research study was carried out to know growth and germination potential of untreated, tap water and hot water treated seeds of four varieties of Moringa oleifera in nursery and field conditions in field area of Koont research farm, Peer Mehar Ali Shah (PMAS), Arid Agriculture University Rawalpindi. After treatment seeds were sown in polythene bags in nursery. Germination of seed was recorded for three weeks in laboratory as well as in nursery conditions and statistically analyzed using ANOVA techniques. Simple water, hot water and control enhanced $60 \%, 71.5 \%$ and $41.75 \%$ germination in this experiment. Hot water treatment has shown maximum germination percentage in all varieties i.e $80 \%$ in Kumasi Middle Ghana, $85 \%$ in Sunyam Middle Ghana, $62 \%$ in Northern Ghana and $59 \%$ in Tehiman Middle Ghana. Maximum plant height $17.12 \mathrm{~cm}$ was recorded in $\mathrm{T}_{2}$ followed by $14.9 \mathrm{~cm}$ and 10.8 in $\mathrm{T}_{1}$ and $\mathrm{T}_{3}$, respectively. In nursery conditions, $\mathrm{T}_{2}$ treated plants had maximum stem diameter which was 2.52 $\mathrm{mm}$ followed by $\mathrm{T}_{1}$ and $\mathrm{T}_{3}$ that was $2.1 \mathrm{~mm}$ and $1.8 \mathrm{~mm}$, respectively. Moringa plants of $\mathrm{T}_{1}$ in field condition had maximum $4.71 \mathrm{~mm}$ diameter significantly greater than $3.87 \mathrm{~mm}\left(\mathrm{~T}_{2}\right)$ and 3.79 $\mathrm{mm}\left(\mathrm{T}_{1}\right)$ respectively.

Keywords: Growth; Moringa; Nursery; Priming Introduction Moringa oleifera, local name "Sohanjna", is a native species of India and is widely distributed in many tropical regions; Pacific region [1], West Africa [2], Central America and the Caribbean [3]. It belongs to an onogeneric family (Moringaceae) of shrubs and tree, originated from Agra and Oudh, the northwest region of India, south of the

Himalayan Mountains. The people of India knew its edible characterization, that's why it can be used as fodder [4] vegetables [5] and medicinal purpose [6]. Agronomic characteristics with slightly basic soils makes it fit to grow in hilly areas but not in waterlogged areas in less fertile acidic soils. However, information about growth of Moringa oleifera in the acidic soil is almost 
absent [7]. Moringa oleifera can grow naturally at an elevation up to $1,000 \mathrm{~m}$ above sea level. It can grow well on hillsides but is more frequently found growing on pastureland or in river basins. It is drought resistant and fast growing $(5-7 \mathrm{~m})$ in one year in arid areas [4].

Moringa oleifera is a multipurpose tree. It has medicinal value and use as a food and fodder for cattle. Oil and curry powder is extracted from seeds of Moringa oleifera. Seeds of Moringa oleifera are also used for cleaning of water. In many regions of the world like in Vietnam, Moringa oleifera leaves are used for food [8]. Moringa foliage is known for its rich protein source, low antinutritional factors [7]. For goat production, the use of grasses as a source of protein is not appropriate because most of the grasses are low in protein. Therefore, Moringa oleifera foliage is a cheap protein source [9].

In Pakistan, pre-sowing seed treatment with different kinds of material i.e. chemicals, salts and other plant growth regulators brings various biochemical changes in germination [10] of seed which are necessary to break seed dormancy. They were used in seed priming to enhance the seed germination, plant growth, and the crop yield [11] but to make process cost effective. Scientists have induced plant extracts for seed priming [12] e.g. Moringa (Moringa oleifera L.) leaves extract (MLE) that not only promotes seed germination but also improves vigor and growth of plants $[13,14]$.

The present study was carried out to determine growth potential of Moringa oleifera in Pothwar region of Pakistan. This study was investigated to assess the germination and growth potential of different varieties of Moringa oleifera in nursery and field conditions.

\section{Materials and methods}

\section{Study area}

Area selected for field experiment was research field of Forestry Department at
Koont Research Farm, PMAS Arid Agriculture University Rawalpindi, situated at Mandra Chakwal Road. It is representative of rainfed areas of Potohar tract. Elevation of the farm is up to 1200 feet. Mean annual rainfall ranges from $450-550 \mathrm{~mm}$.

\section{Research design}

Research work consisted of lab and field experiments

For laboratory experiment CRD Design was used with three treatments i.e simple water $\left(T_{1}\right)$, Hot water $\left(T_{2}\right)$, control $\left(T_{3}\right)$ and four varieties i.e (1) Kumasi Middle Ghana (2) Sunyam Middle Ghana (3) Northern Ghana (4) Tehiman Middle Ghana. For field study randomized complete block design was used.

\section{Germination tests in laboratories}

Healthy and vigorous seeds were taken from Forestry Department of Bahauddin Zakariya University, Multan. Seeds were treated with three different treatments and were sown in soil of uniform composition to identify seed germination rate.

To determine Cumulative germination percentage, the following formula was used

$\mathrm{CG} \%=\underline{\text { Total number of seeds that germinated }} \times 100$ Number of seeds sown

\section{Control}

Seeds of Moringa oleifera were placed in petri dishes without any treatment and germination was noticed every other other day for three weeks [16].

\section{Simple water treatment}

Seeds of Moringa oleifera were submerged in normal water for 24 hours. Seeds were placed in petri dishes. Germination of seeds was noticed every other day for three weeks [16].

\section{Hot water treatment}

Seeds of Moringa oleifera were submerged in $80^{\circ} \mathrm{C}$ boiled water for 5 minutes and soaked in lukewarm water for 12 hours. Seeds were placed in petri dishes. Germination was noticed every other day for three weeks [16]. 


\section{Field experiment}

Seed sowing

Seeds were sown in $8 \times 4$ inches' polythene tubes filled with soil at the end of june at the depth 3 times of seed size.

\section{Seed germination}

Seed germination was recorded for three weeks. Seedlings were watered according to soil condition. At the end of July (monsoon season), seedling were shifted from nursery to field and growth parameters were recorded on weekly basis for two months.

\section{Growth parameters}

1) Number of Leaves

2) Plant Height

3) Stem Diameter

\section{Number of leaves}

Leaves of Moringa oleifera were counted manually at weekly basis.

\section{Stem diameter and plant height}

Measuring tape was used for diameter and height measurement of all plants. Diameter of plant stem was determined by the following formula.

Diameter $=$ Girth $/ \pi$ where $(\pi=3.14)$

Girth = Circumference of plant stem

\section{Statistical analysis}

The data was analyzed by using statistical software (Statistix 8.1) for windows. The most significant seed treatment and its effects on growth parameters were determined by applying statistical test (ANOVA) on data. Means of significant effects were determined by using LSD at 5 percent probability level [17].

\section{Results and discussion Germination test in laboratory}

In figure 1 indicates effect of treatments on germination percentage of Moringa oleifera. Mean germination percentage differs statistically in all treatments. Maximum germination percentage (72\%) was recorded in hot water treated seeds that was statistically higher than $(48.5 \%)$ of tape water and $(42.5 \%)$ control respectively.

In figure 2 elaborates germination percentage of different varieties of Moringa oleifera. Sunyam Middle Ghana have $78.5 \%$ seed germination that was significantly greater than Kumasi Middle Ghana (67.3\%), Northern Ghana $(56.5 \%)$ Tehiman Middle Ghana i.e. $28.33 \%$.

In figure 3 depicts that seed treated with hot Water treatment had germination@85\% in Sunyam Middle Ghana, which was at par 80 $\%$ in Kumasi Middle Ghana was significantly greater than $62 \%$ in Northern Ghana and 59 $\%$ in Tehiman Middle Ghana. Seed treated with water had $70 \%$ germination while Middle Ghana had only $48 \%$ germination. These results have close junction with [13], who have increased germination percentage with pre sowing seed treated.

\section{Field experiment}

Plant Height

In figure 4 illustrates variation in plant height with seed treatments. Maximum plant height was $(17.12 \mathrm{~cm})$ recorded in $\mathrm{T}_{2}$ that was significantly higher than $14.9 \mathrm{~cm}$ and 10.8 in $\mathrm{T}_{1}$ and $\mathrm{T}_{3}$, respectively in lab while $23.94 \mathrm{~cm}$ long plants were found in $\mathrm{T}_{1}$ that was literally at par with 21.9 and $21.15 \mathrm{~cm}$ in $\mathrm{T}_{2}$ and $\mathrm{T}_{3}$ respectively. The reason of more plant height in field is explained by $[8, \mathbf{1 0}]$ relating more moisture, nutrients availability due to field system and availability of organic carbon. 


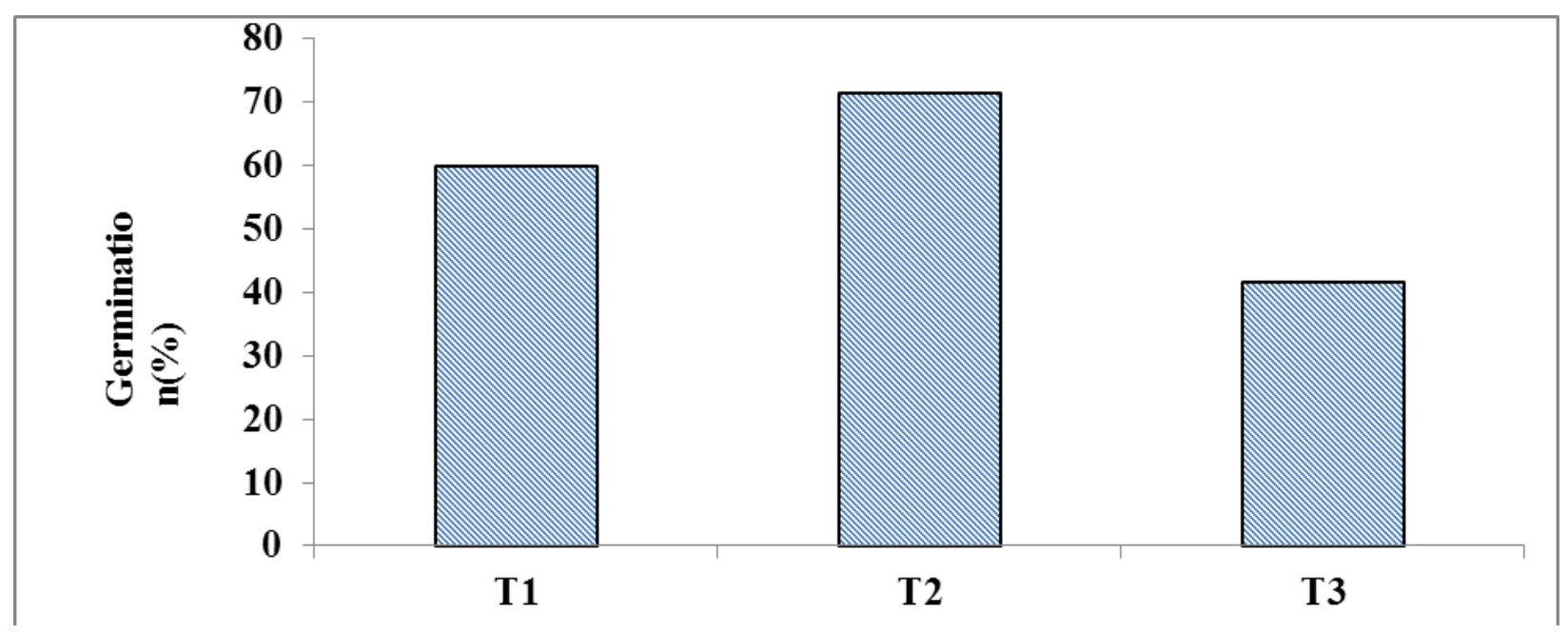

Figure 1. Germination percentage of Moringa oleifera under different treatments

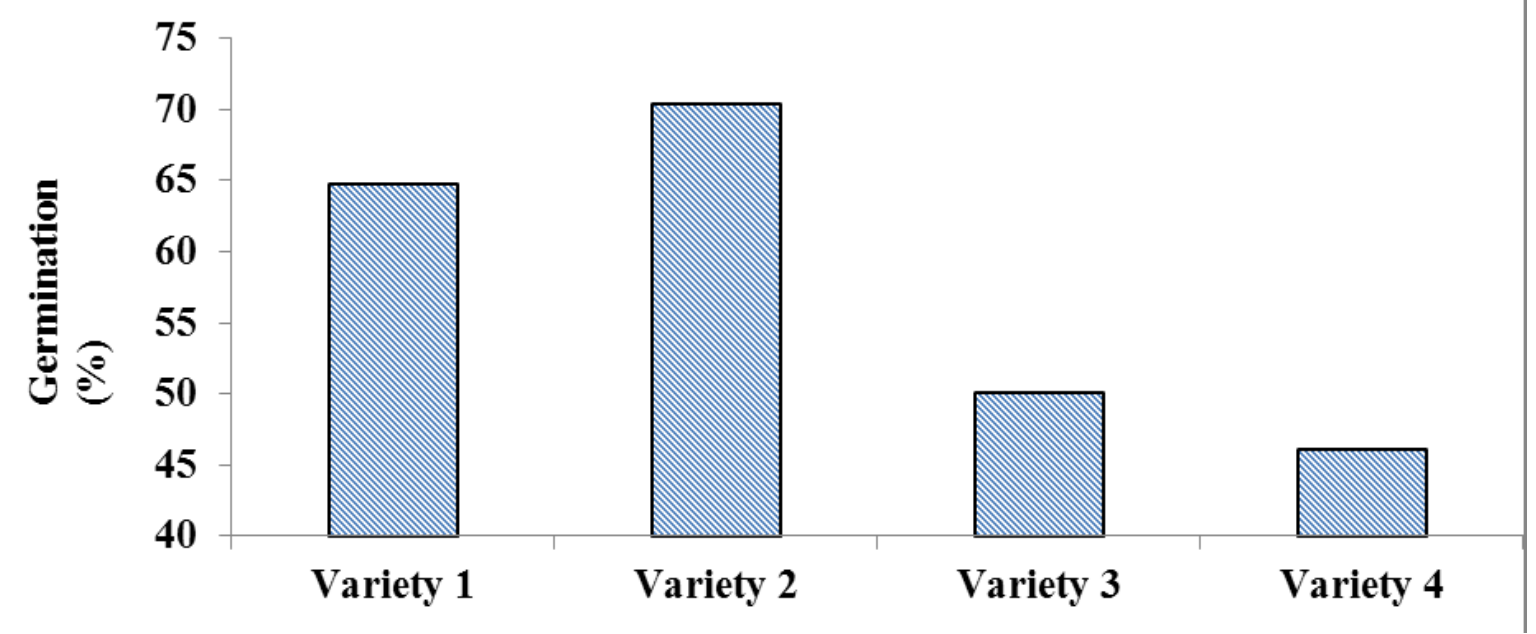

Figure 2. Germination percentage of different varieties of Moringa oleifera

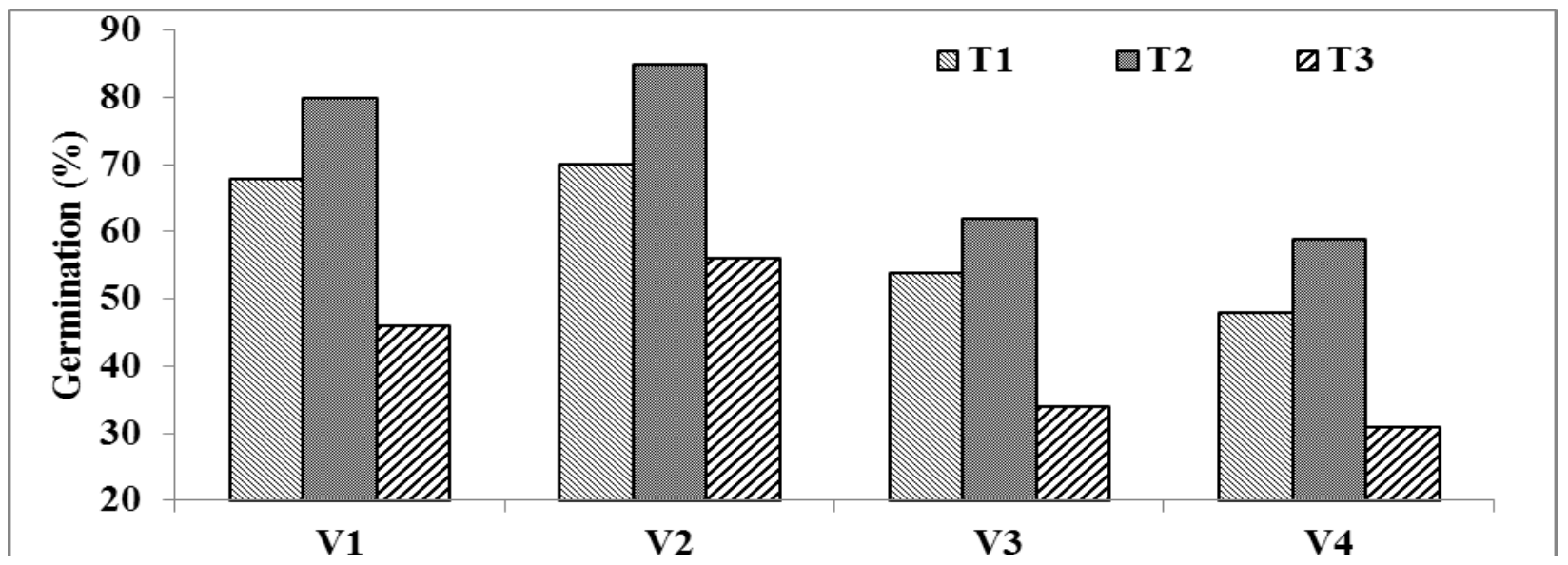

Figure 3. Effect of different treatments on germination percentage of different varieties of Moringa oleifera 


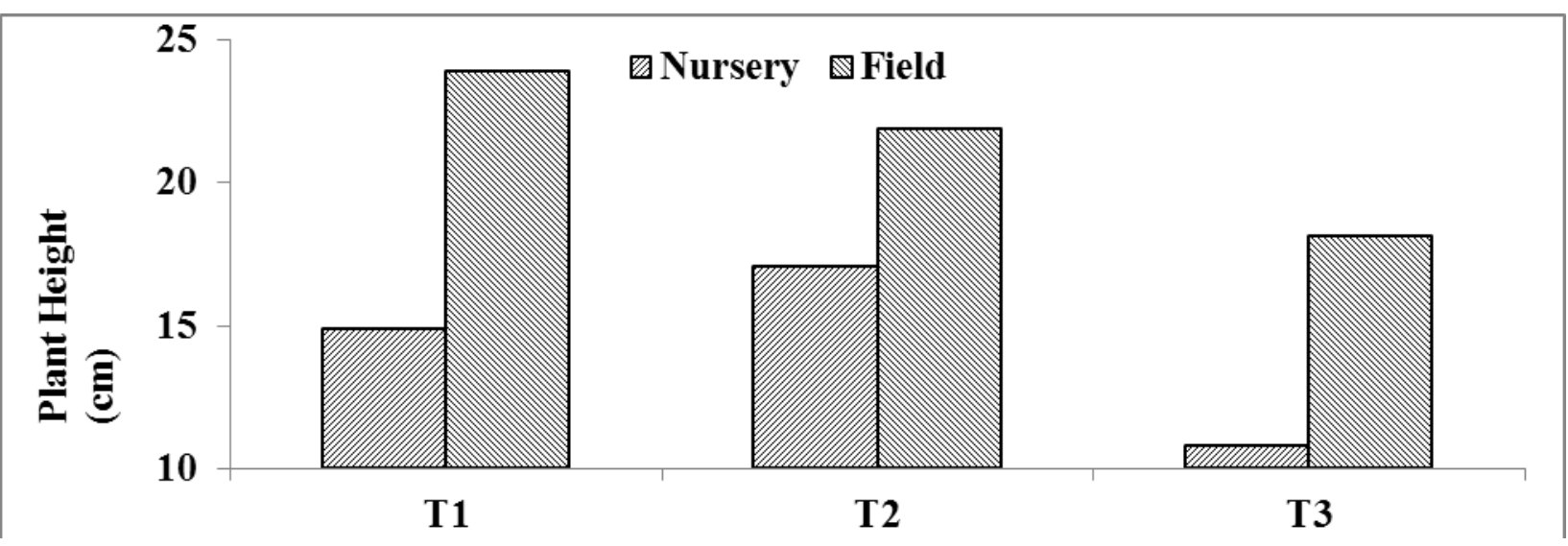

Figure 4. Height of Moringa oleifera in different treatments

\section{Number of leaves}

In figure 5 shows the data recorded for effects of different seed treatments on number of leaves of plant. Simple water treated plants have maximum number of Moringa leaves 52 followed by 46 that was followed by 33 leaves in nursery. In field conditions, the leaf count of $\mathrm{T}_{1}$ was 301 leaves and then followed by 224 leaves, while $T_{3}$ plants produced 172 leaves after two months of growth. This data also shows that maximum number of leaves (301) were reported in field conditions while minimum number of leaves (33) at nursery level. Seed soaking helps in germination and root extension in fields helps plant to uptake more nutrients $[10,15]$ that ultimately result in production of more leaves in Moringa oleifera.

\section{Diameter}

Different treatments effect on mean diameter of Moringa oleifera plant is shown in figure 6. Different treatments gave statistically different stem diameter plants in nursery and field conditions at $5 \%$ significance level. In nursery conditions, $\mathrm{T}_{2}$ yielded $2.52 \mathrm{~mm}$ diameter followed by $2.1 \mathrm{~mm} \mathrm{~T}_{1}$ and $\mathrm{T}_{3} 1.8$ $\mathrm{mm}$. In field conditions, $\mathrm{T}_{1}$ produced maximum diameter of $4.71 \mathrm{~mm}$ that was significantly higher than $\mathrm{T}_{2}$ and $\mathrm{T}_{3}$ which gave diameter of $3.87 \mathrm{~mm}$ and $3.79 \mathrm{~mm}$ respectively. Environmental conditions, soil conditions, nutrients availability in field is main cause of increase in plant girth in field condition $[8,10]$.

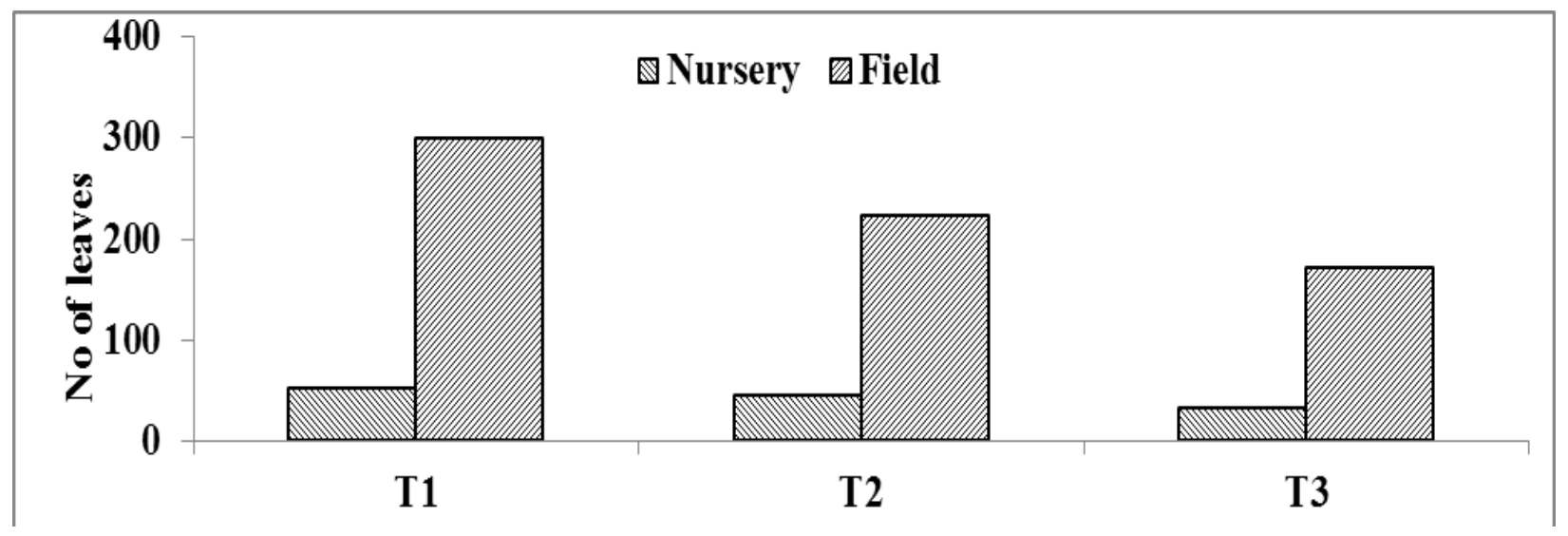

Figure 5. Number of leaves of Moringa oleifera in different treatments 


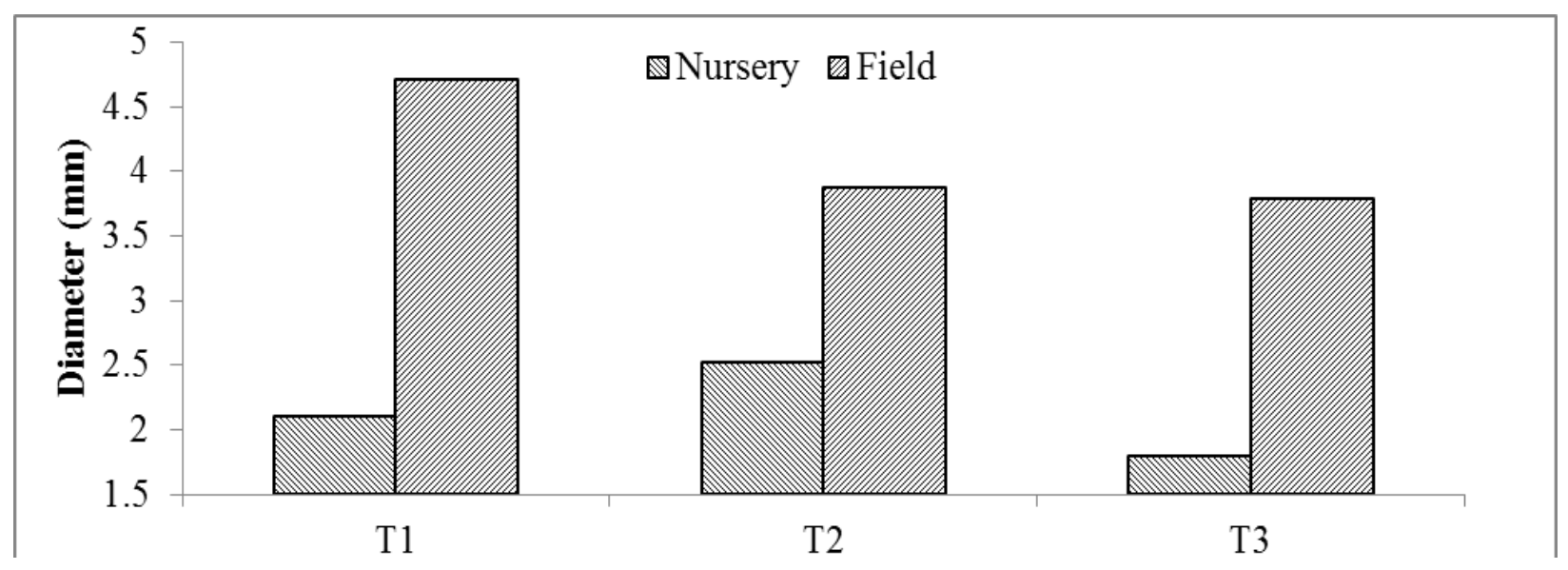

Figure 6. Diameter of Moringa oleifera in different elements

\section{Conclusion and recommendations}

Moringa oleifera is a fast growing multipurpose tree species. It can grow and survive in water stress conditions, all type of soil except acidic soil, water logging, highly susceptible to frost, grow well on foothills up to $1000 \mathrm{~m}$ elevation. It can be used as a food and fodder, having medicinal value and used for cleaning of water. It can be easily grown in hilly areas of Pakistan, pothwar region and southern districts of Khyber Pakhtunkhwa. Seed treatments have a beneficial effect on the germination of seeds and other growth parameters. Hot water treatment is easy and fruitful method for breaking seed dormancy. Authors' contributions

Conceived and designed the experiments: $\mathrm{S}$ Fahad, N Latif \& SN Mirza, Performed the experiments: S Fahad \& SN Mirza, Analyzed the data: H Shahzad, M Rizwan \& MA Khan, Wrote the paper: S Ullah.

\section{Acknowledgments}

Contribution of Department of Forestry and Range management, PMAS, Arid Agriculture University, Rawalpindi, Pakistan for providing field, pots and other research material.

\section{References}

1. Aregheore EM (2002). Intake and digestibility of Moringa oleifera-batiki grass mixtures by growing goats. Small Rumin Res 46: 23-28.

2. Lockett CT, C1alvert CC \& Grivetti LE (2000). Energy and micronutrient composition of dietary and medicinal wild plants consumed during drought. Study of rural Fulani, Northeastern Nigeria. Int J Food Sci Nutr 51: 195-208.

3. Ramachandran C, Peter KV \& Gopalakrishnan PK (1980). Drumstick (Moringa oleifera): a multipurpose Indian vegetable. Econ Bot 34: 276-283.

4. Odee D (1998). Forest biotechnology research in drylands of Kenya: the development of Moringa species. Dryland Biodivers 2: 7-12.

5. Morton JF (1991). The Horseradish Tree, Moringa pterygosperma (Moringaceae) - A Boon to Arid Lands. Econ Bot 45: 318-333.

6. Sarwatt SV, Milang'ha MS, Lekule FP, \& Madalla N (2004). Moringa oleifera and cottonseed cake as supplements for smallholder dairy cows fed Napier grass. Livest Res Rural Dev 16: 38-39.

7. Pham HH (1972). Illustrated Flora in the South of Vietnam.

8. Luu HM, Dung NNX \& Xuan VT (2003). Biomass production of some legumes in the hilly area of Thinh Bien 
District, An Giang Province. In: Proceedings of Final National SeminarWorkshop on Sustainable Livestock Production on Local Feed Resources (Editors: Reg Preston and Brian Ogle). HUAF-SAREC, Hue City 25 - 28 March, 2003.

9. Khan A, Khalil SK, Khan AZ, Marwat KB \& Afzal A (2008). The role of seed priming in semi-arid area for mungbean phenology and yield. Pak J Bot 40: 2471-2480.

10. Khalil SK, Rehman A, Khan AZ, Wahab S, Zubair M, Khalil IH, \&Mohammad F (2010). Soybean mother plant exposure to temperature stress and its effect on germination under osmotic stress. Pak J Bot 42: 213-225.

11. Farooq M, Wahid A, Ito O, Lee DJ \& Siddique KHM (2009). Advances in drought resistance of rice. Crit Rev Plant Sci 28: 199-217.

12. Chung IM \& Miller DA (1995). Effect of alfalfa plant and soil extracts on germination and growth of alfalfa. Agron $J$ 87: 762-767.
13. Nouman W, Siddiqu MT and Basra SMA (2012). Moringa oleifera leaf extract (MLF) An innovative priming tool for rangeland grasses. Turkish $J$ Agric For 36: 65-75.

14. Freiberger C, Vanderjagt E, Pastuszyn DJ, Glew A, Mounkaila RS, Millson G \& Glew RH (1998). Nutrient content of the edible leaves of seven wild plants from Niger. Plant Foods Hum Nutr 53: 57-69.

15. Fuglie LJ (2001). The Miracle Tree: Moringa oleifera: Natural nutrition for the tropics. Training manual. Church world service, Dakar, Senegal 23-35.

16. Azad MS, Mausa MZA, \& Matin MA (2010). Effect of pre sowing treatments on germination of Melia azadarach. $J$ For Res 21(2): 193-196.

17. Steel RGD, Torrie JH \& Deckey DA (1997). Principles and procedure of statistics. A biometrical approach. $3^{\text {rd }}$ Ed. Mc Gaw Hill Bookco., New York, USA. 